\title{
HANGING AS A METHOD OF SUICIDE RETROSPECTIVE ANALYSIS OF POSTMORTEM CASES
}

\author{
Ahmad $\mathrm{M}^{1}$, Hossain $\mathrm{MZ}^{2}$
}

\begin{abstract}
This retrospective study was conducted on 145 postmortem cases of hanging victims at government medical college morgue over a period of two years. The objective of this study was to find out the pattern of hanging cases as a proper method of suicide and to evaluate the present situation of hanging in this capital city. Out of 145 cases, $41 \%$ were male and $51 \%$ were married. One hundred and one victims hanged themselves at night, while 44 at day time. In 72 victims, stomachs were found empty. Most (97\%) of the bodies were recovered from inside the living rooms. Ninety seven percent had complete suspension. One hundred and forty two $(\mathbf{9 8 \%})$ cases had ligature mark in neck. Thirty nine cases had fracture of hyoid bones, 27 cases had fracture of thyroid cartilages. Most of the victims (45\%) were from the age group 20- 30 years. Dopatta (orna) was the commonest (35\%) ligature material. Quarrel among husband and wife was the commonest (31\%) cause of suicidal hanging. Hanging was observed as a frequently used method of suicide in Bangladesh.

Key words: Hanging, suicide, post mortem
\end{abstract}

\section{Introduction}

Hanging is a form of violent asphyxial death in which the body is suspended by a ligature from above that constricts the neck and prevents entry of air into lungs. The constricting force is the weight of the body ${ }^{1}$. Sometimes the body completely suspends from above and is called complete hanging. When some part of body touches the ground, the procedure is called incomplete or partial hanging ${ }^{2}$. A good number of people die each year by suicide, making it one of the 10 leading causes of death in the world accounting more than a million death annually ${ }^{3}$. Hanging produces painless death for the victims and there is no costs involvement other than that of the ligature material. A thin rope around the neck will cause unconsciousness in 15 seconds $^{4}$. So the people prefer it as a common method of suicide in Bangladesh. Although there are other means of suicide in Bangladesh, like intake of overdoses of barbiturate tablets in urban area and organo phosphorus compounds (insecticides) ingestion in rural area. These methods are also followed in other south Asian countries ${ }^{5,6}$. Even in developed countries like Serbia, Norway or Hungary suicide by hanging is the commonly observed procedure ${ }^{7-9}$. In England and Wales hanging is the commonest method of suicide, accounting 2000 deaths each year ${ }^{10}$.

\section{Materials and Methods}

This retrospective study was conducted among victims of hanging brought to Sir Salimullah Medical College (SSMC) morgue during the period January 2003 to December 2004. Various identification data of the victim like age, sex, marital status, permanent address, suspension of dead body along with places of incidence, time and suspected causes of death were noted from the inquest report accompanying the dead bodies. The preliminary investigating report submitted by the police (inquest report) played very important role in this regards. Other related information were gathered from the victims attendants. Points regarding knot of ligature material, injury to neck structures, stomach condition were noted during post mortem examinations.

\section{Results}

Out of 145 cases, $60(41.37 \%)$ were male and 85 (58.62 $\%)$ were female. Among these victims 74 (51.03\%) were married and $71(48.96 \%)$ were unmarried. Most of the victims $(45.51 \%)$ were from the age group 20-30 years followed by 55 (37.93\%) from ages $11-20$ years (Table-I).

Table-I : Variation of ages in the victims $(n=145)$.

\begin{tabular}{|c|c|c|c|}
\hline \multirow{2}{*}{$\begin{array}{c}\text { Age group } \\
\text { in year) }\end{array}$} & \multicolumn{2}{|c|}{ Cases received in } & \multirow{2}{*}{ Total } \\
\cline { 2 - 3 } & $\mathbf{2 0 0 3}$ & $\mathbf{2 0 0 4}$ & \\
\hline $01-10$ & $02(02.41 \%)$ & $01(01.61 \%)$ & $0302.07 \%)$ \\
\hline $11-20$ & $32(38.55 \%)$ & $23(37.09 \%)$ & $55(37.93 \%)$ \\
\hline $21-30$ & $36(43.37 \%)$ & $30(48.38 \%)$ & $66(45.51 \%)$ \\
\hline $31-40$ & $07(08.43 \%)$ & $05(08.06 \%)$ & $12(08.27 \%)$ \\
\hline $41-50$ & $05(06.02 \%)$ & $03(04.83 \%)$ & $08(05.51 \%)$ \\
\hline $51-60$ & $01(01.20 \%)$ & 00 & $01(00.69 \%)$ \\
\hline Total & $83(57.24 \%)$ & $62(42.76 \%)$ & 145 \\
\hline
\end{tabular}

One hundred and one victims (69.65\%) hanged themselves at night, while $44(30.34 \%)$ at day time. In 72 victims $(45.65 \%)$, stomachs were found empty. One hundred and forty two bodies $(97.93 \%)$ were recovered from inside the living rooms and $03(2.06 \%)$ from outside. One hundred and forty one victims (97.24\%) 
had complete suspension and $04(2.76 \%)$ were cases of partial hanging. Considering the knot, most were situated at right side of neck $(45.51 \%)$, followed by left side $(38.62 \%) .142(97.93 \%)$ cases had ligature mark in neck. Thirty nine $(26.89 \%)$ cases had fracture of hyoid bones, $27(18.62 \%)$ cases had fracture of thyroid cartilages Dopatta (orna) was the commonest (35.17\%) ligature material used for hanging purpose (Table-II) Cervical spinal cord injury was not found in any of those studied case. Family quarrel among husband and wife was the commonest (31.03\%) cause of suicidal hanging (Table-III).

Table-II: Variation of ligature materials used for hanging $(n=145)$.

\begin{tabular}{|l|c|c|c|}
\hline \multirow{2}{*}{$\begin{array}{l}\text { Ligature } \\
\text { materials }\end{array}$} & \multicolumn{2}{|c|}{ Cases received in } & \multirow{2}{*}{ Total } \\
\cline { 2 - 3 } & $\mathbf{2 0 0 3}$ & $\mathbf{2 0 0 4}$ & \\
\hline $\begin{array}{l}\text { Orna } \\
\text { dopatta })\end{array}$ & $32(38.55 \%)$ & $19(30.64 \%)$ & $51(35.17 \%)$ \\
\hline Jute rope & $25(30.12 \%)$ & $23(37.09 \%)$ & $48(33.10 \%)$ \\
\hline Shari & $14(16.86 \%)$ & $11(17.74 \%)$ & $25(17.24 \%)$ \\
\hline $\begin{array}{l}\text { Nylon } \\
\text { rope }\end{array}$ & $06(07.22 \%)$ & $06(09.67 \%)$ & $12(08.27 \%)$ \\
\hline Towel & $04(04.82 \%)$ & $03(04.84 \%)$ & $07(04.83 \%)$ \\
\hline Kamij & $01(01.20 \%)$ & 00 & $01(00.69 \%)$ \\
\hline $\begin{array}{l}\text { Electric } \\
\text { wire }\end{array}$ & $01(01.20 \%)$ & 00 & $01(0.069 \%)$ \\
\hline Total & $83(57.24 \%)$ & $62(42.76 \%)$ & 145 \\
\hline
\end{tabular}

Table-III: Suspected causes of hanging $(n=145)$.

\begin{tabular}{|l|c|c|c|}
\hline \multirow{2}{*}{$\begin{array}{l}\text { Causes of } \\
\text { hanging }\end{array}$} & \multicolumn{2}{|c|}{ Cases received in } & \multirow{2}{*}{ Total } \\
\cline { 2 - 3 } & $\mathbf{2 0 0 3}$ & $\mathbf{2 0 0 4}$ & \\
\hline $\begin{array}{l}\text { Quarrel } \\
\text { between } \\
\text { couples }\end{array}$ & $28(33.73 \%)$ & $17(27.41 \%)$ & $45(31.03 \%)$ \\
\hline $\begin{array}{l}\text { Failure in } \\
\text { love affairs }\end{array}$ & $06(07.22 \%)$ & $07(11.29 \%)$ & $13(08.96 \%)$ \\
\hline $\begin{array}{l}\text { Drug } \\
\text { addiction }\end{array}$ & $07(08.43 \%)$ & $05(08.06 \%)$ & $12(08.27 \%)$ \\
\hline $\begin{array}{l}\text { Incurable } \\
\text { disease }\end{array}$ & $03(03.61 \%)$ & $08(12.90 \%)$ & $11(07.58 \%)$ \\
\hline $\begin{array}{l}\text { Mental } \\
\text { depression }\end{array}$ & $06(07.22 \%)$ & $04(06.45 \%)$ & $10(06.89 \%)$ \\
\hline $\begin{array}{l}\text { Family } \\
\text { problems }\end{array}$ & $03(03.61 \%)$ & $05(08.06 \%)$ & $08(05.51 \%)$ \\
\hline $\begin{array}{l}\text { Unwanted } \\
\text { pregnancy }\end{array}$ & $04(04.81 \%)$ & $03(04.83 \%)$ & $07(04.82 \%)$ \\
\hline $\begin{array}{l}\text { Mentally } \\
\text { imbalance }\end{array}$ & $02(02.40 \%)$ & $03(04.83 \%)$ & $05(03.44 \%)$ \\
\hline Unknown & $24(28.91 \%)$ & $10(16.13 \%)$ & $34(23.45 \%)$ \\
\hline Total & $83(57.24 \%)$ & $62(42.76 \%)$ & 145 \\
\hline
\end{tabular}

\section{Discussion}

In this study $58.63 \%$ were female and rests were male. Among them 51.04\% were married. Family quarrel among husband and wife was the commonest cause $(31.03 \%)$ observed for suicidal hanging. It was observed that in Bangladeshi socioeconomic condition male are predominantly earning member of the family and husbands torture or harass the wives for various family problems including dowry. Female are comparatively less educated. They have low frustration tolerance level and weak protective value in social institute like family specially in low socioeconomic condition. Due to repeated physical and mental torture, they go beyond the threshold level of self constrain and commit suicide by easily available ligature material like dopatta or shari or rope. In case of male; poverty, lack of job, family problems, defamation and alcoholism are the main reason for suicidal hanging. These causative factors are similar to those in India ${ }^{11,12}$. Sometimes the victims leave behind a suicidal note, which indicate the exact causes behind these suicides. Exact number of suicidal deaths by hanging in Bangladesh are not known but in the neighboring country India, every 5 minutes a person commits suicide, 7 attempt to kill themselves forming around 1,00,000 suicide death per year; either by hanging or ingestion of insecticides or barbiturate tablets $^{13}$. A five year study (1998 to 2002) in Turkey also showed that hanging was the commonest method of suicide in Istanbul ${ }^{14}$. A study in Lithuania showed that a total of 8324 suicides were committed during 1993 to 1997 and 7823 during 1993 to 2002. Among all these registered suicides cases, hanging was the commonest method used to commit suicide ${ }^{15}$.

In present study most of the victims were from the age group 20-30 years (45.51\%). Study has shown that people belong to this age group were also common victims of hanging in other countries ${ }^{16}$. In middle and higher class family, members of this younger group belong to student community. In low socio economic family they are the earning members like garments or other industrial workers. They commit suicides due to failure in love affairs $(8.96 \%)$, drug addiction $(8.27 \%)$, unwanted pregnancy $(4.82 \%)$ and mental depression $(6.89 \%)$, which are the common problems among this age group. Even failure in examination can also lead to suicide, which is a tragic and preventable public health problem all over the world. In both developed and developing countries the suicide rate among young people appears to be rising ${ }^{17}$. Peer pressure and emotional issues are the triggering factors. In this study only 01 case of hanging was found above 50 years and no cases were found beyond 60 years of age .The reason could be the family system of this country in which elders are taken care of by earning family members and the elders enjoy their advancing life with grand children and increase inclination towards religious matters.

About the religion, 130 victim were Muslim, 9 were Hindu, 4 were Buddhist and 2 were Christians, indicating most of the worshipers in Bangladesh are Muslims. Most of the victims (69.65\%) hanged 
themselves at night. The stomachs were found empty $45.65 \%$ victims and $97.93 \%$ bodies were recovered from inside the living rooms. After whole days of work, when the victims return home at night, they become exhausted with their brain full of problems and burdens, initiating reflexes for suicidal tendency. A number of victims committed suicide at late night, which is the explanation of empty stomach. More over at dead of night and inside the room, there would be no one to resist them from suicidal behavior.

Dopatta is about ten feet long cloth used by the ladies to cover the head and chest. Subjects of this study most commonly (35.17\%) used this as ligature material. 141 victims had complete suspension (97.24\%) and 04 were cases of partial hanging $(2.75 \%)$. Salwar kamiz is the most common dress used by the female population of this country, hence dopatta (orna) is used as commonly available ligature material for hanging. The victims hanged themselves from ceiling fan, beams, girder etc. using a chair or table or tool as the base for standing, later on push them away by feet. Hence most had complete suspension. In the outdoor cases branch of a tree was commonly used as the point of suspension. In western countries dog lead, belt, electric cable, scarf, tie, dressing gown cord, shoe lace etc are used as ligature materials, which are not so used in Bangladesh ${ }^{18}$. Moreover firearms play important role as a method of suicide, which are not commonly available in this country.

In most cases knots hanging loops were situated at right side of neck $(45.51 \%)$ and rests on left side. Knot on right side of neck is commonly available for right hand users, who are more abundant in this country than left hander. This coincides with other studies performed before $^{19}$. Hundred and forty two cases had ligature mark in neck. This mark appears as a furrow on the skin whose direction is determined by the point of suspension. Depending upon duration of suspension it may show light brown or yellow parchment like areas ${ }^{20}$. Among the victims, $26.89 \%$ cases had fracture of hyoid bones, $18.62 \%$ cases had fracture of thyroid cartilages. Number of fracture increases with advancing age. Most of the victims had injury to the sternoclidomastoid muscles. These findings coincide with studies done before ${ }^{21}$. Complete disruption of atlanto-occipital joint, cervical spine or spinal cord was not found in any of these cases since all the cases were suicidal in nature and mostly recovered from inside the room. It is very unusual for the cervical spine to be broken in suicidal hanging cases unless there is long drop, which usually occur when the victim selects a branch of a high tree as the point of suspension for hanging. These disruptive changes are commonly observed in judicial hanging cases ${ }^{22}$.

\section{Conclusion}

The number of suicidal hanging cases is increasing day by day. A well designed and comprehensive programme is needed to identify the causative factors and prevention of suicidal behaviors. Appropriate education, influencing the media in their portrayal of suicidal news, reporting method, involvement of young generations in encouraging activities may reduce the rate of suicidal death by hanging in future.

\section{References}

1. Reddy KSN. The Essentials of Forensic Medicine \& Toxicology. 29th ed. India: Medical Book Coy; 2010. p. 296-297.

2. Nandy A. Principle of Forensic Medicine including Toxicology. 3rd ed. India: Central Book Agency; 2010. p.517-518.

3. Mohanty S, Sagu H, Mohanty MK, Patnaik M. Suicide in India: A four year retrospective study. J Forensic Leg Med 2007; 14(2): 185-189.

4. Knight B, Pekka S. Knight's Forensic Pathology. 3rd ed. London: Arnold;2004.p. 352- 380.

5. Galgali RB , Sanjeeb R, Ashok MV, Appaya P, Srinivasan K. Psychiatric diagnosis of self poisoning Cases ; a general hospital study . Ind J Psych 1998; 40(3): 254-259.

6. Kandamuthan M. Preliminary findings on the Psychosocial factors for attempt of suicide in Kerala. NIMHANS J 1998; 1: 261-70.

7. Nikolic S, Micic J, Atanasijevic T, Djokic V, Djonic D. Analysis of neck injuries in hanging. Am J for Med Path 2003; 24(2): 179-182.

8. Morild I. Fractures of neck structures in Suicidal hanging. Med Sci Law 1996; 36(1): 80-84.

9. Toro K, Krostof I, Keller E. Incomplete decapitation in suicidal hanging- report of a case and review of the literature. J For Leg Med 2008; 15(3): 180-184.

10. Brock A, Griffiths C. Trends in Suicide by method in England and Wales, 1979- 2001. Health Stat Quart 2003; 20 : 7-18.

11. Gupta SC, Singh H. Psychiatric illness in Suicidal attempters. Ind J Psychiatry 1981; 23(1): 69-74.

12. Narang RL, Mishra BP, Nitesh M. 2000 Attempted suicide in Ludhiana. Ind J Psychiatry 2000; 42(1): 83-87.

13. Sanjush B, Manju PH, Yesudas KF. Psychiatric diagnosis in attempted suicide. Cal Med J 2006; 4(3): e2.

14. Uzun I, Buyuk Y, Gurpinar K. Suicidal Hanging : Fatalities In Istanbul Retrospective Analysis Of 761 Autopsy Cases . J For Leg Med 2007; 14(7): 406-409.

15. Starkuviene S, Kalediene R, Petrauskiene J. Epidemic of Suicide by hanging in Lithuania : does socio demographic status matter ? Pub Health 2006;120(8): 769-775.

16. Sharma BR, Harish D, Sharma A, Sharma S, Singh H. Injuries to neck structures in deaths due to constriction of neck, with a special reference to hanging. J For Leg Med 2008 ;15(5): 298- 305.

17. Eddlesto M, Rezvi SMH,Hawton K. Deliberate Self Harm in Srlanka; an overlook tragedy in the developing world. BMJ 1998; 7151: 133-135.

18. Bennewith O, Gunnel D, Kapur N, Simkin S. Suicide by hanging: multi centre study based on coroners records in England. BMJ 2005; 186: 260-261.

19. Talukder MA, Mansur MA, Kadir MM. 2008 Incidences of Typical and Atypical hanging among 66 hanging cases. Mymensingh Med J 2008; 17(2): 149-151.

20. Sharma BR,Harish D, Singh VP, Singh P. Ligature mark on neck: how informative? J Ind Aca For Med 2005;27(1):10-15.

21. Slobodan N, Jelena M, Tatjana A, Vesna D, Danijela D. Analysis of neck injuries in hanging. Am J For Med \& Path 2003; 24(2): 179-182.

22. Shepherd R. Simpon's Forensic Medicine. 12th ed. London: Arnold Publishers; 2003. p.98- 101. 